\title{
STRATEGI PENINGKATAN PENERIMAAN PAJAK BUMI DAN BANGUNAN (PBB) DI KOTA BATU
}

\author{
Rambu Trio Lita Baok, Totok Sasongko, Muhamad Rifa'i \\ Universitas Tribhuwana Tunggadewi \\ Email: rambutriolitabaok@gmail.com
}

\begin{abstract}
Abstrak: Upaya penerimaan pajak bumi dan bangunan di kota Batu diupayakan untuk selalu mengalami peningkatan pada setiap tahunnya, namun dalam pelaksanaannya masih terdapat masalah yaitu banyak masyarakat yang kurang memperhatikan dalam membayar pajak, masyarakat selalu menunggu saat jatuh tempo dalam membayar pajak, terkadang juga para pemungut pajak merasa kesulitan dalam mencari alamat wajib pajak untuk memberikan SPPT. Penelitian ini menggunakan pendekatan kualitatif dengan teknik pengumpulan data melalui wawancara, observasi, dan dokumentasi, informan dalam penelitian ini adalah Staf Badan Keuangan Daerah Kota Batu dan masyarakat Kota Batu. Uji keabsahan data menggunakan trianggulasi teknik. Analisis data dilakukan dengan reduksi data, penyajian data, dan penarikan kesimpulan. Hasil penelitian menujukkan strategi yang dilakukan badan keuangan daerah kota batu untuk meningkatkan penerimaan pajak bumi dan bangunan sudah cukup baik, yakni mengalami peningkatan pada tiga tahun terakhir. Pembayaran pajak dilakukan di Bank Jatim atas dasar kerjasama, melakukan sosialisasi dan himbauan secara inten ke desa-desa, membuat perlombaan di masyarakat terkait pembayaran pajak. Kendala yang menghambat peningkatan penerimaan PBB di kota Batu selama ini adalah wajib pajak tidak berada di tempat, dan juga para wajib pajak selalu menunggu tanggal jatuh tempo.
\end{abstract}

Kata Kunci: Strategi, Pajak, Bumi Dan Bangunan

\begin{abstract}
The efforts to receive land and building tax in Batu city are strived for increasing constantly every year, but there are still problems in the implementation which many people less attention for paying taxes, people are always waiting when due in paying taxes, sometimes tax collectors also are difficult in finding the address of taxpayers to provide SPPT. This study use qualitative approach with data collection techniques which are interviews, observations, and documentation, the informants in this study are the staff Regional Finance Agency of Batu City and societies Batu City. Test the data validity uses triangulation techniques. Data analysis was done with data reduction, data presentation, and making conclusions. The results of the research show that the strategy done by Regional Financial Agency of Batu City to increase land and building tax revenue is quite good, which has increased in the last three years. Tax payments are made at Bank Jatim on the basis cooperation, socializing and appealing to villages intantly, making competitions in the community related to tax payments. The obstacle that inhibit increasing of PBB revenue in Batu city all this time is taxpayers are not in the place, and also taxpayers are always waiting for the due date.
\end{abstract}

Keywords: strategy, tax, land and building.

\section{PENDAHULUAN}

Strategi pembagunan suatu daerah pada saat ini hendaknya lebih diarahkan pada pembangunan kemandirian disektor ekonomi. Kemandirian ini termasuk dalam hal pembiayaan pembagunan. Penerimaan sumber pendapatan daerah dalam melaksanakan desentralisasi diatur dalam Undangundang Nomor 28 tahun 2009, yaitu dalam rangka penyelengaraan Pemerintah. Setiap daerah mempunyai hak dan kewajiban untuk mengatur dan mengurus sendiri urusan pemerintahannya guna meningkatkan efisiensi dan efektivitas penyelengaraan pemerintahan guna memberikan pelayanan kepada masyarakat. Dalam rangka pelaksanaan operasionalisasi penyelenggaraan pemerintahanan, daerah diperbolehkan untuk mengenakan pungutan pada masyarakat. Berdasarkan UUD RI tahun 


\section{REFORMASI}

ISSN 2088-7469 (Paper) ISSN 2407-6864 (Online)

Volume 10 Nomor 1 (2020)

1945 yang menetapkan perpajakan sebagai salah satu perwujudan kenegaraan, yang menegaskan bahwa penempatan beban kepada masyarakat, seperti pajak dan pungutan lain yang bersifat memaksa telah diatur oleh undang-undang.

Salah satu cara memenuhi kebutuhan operasional penyelenggaraan pemerintahan dapat diperoleh dari sektor pajak, dimana pajak merupakan salah satu sumber penting dari segi penerimaan negara guna pembiayaan pembagunan. Akan tetapi upaya mendapatkan pemasukan tersebut juga masih banyak mengalami kendala, salah satunya masih banyak masyarakat yang belum sadar tentang kewajiban membayar pajak, manfaat pajak untuk pembangunman, serta menunggu jatuh tempo dalam pembayaran. Penyebab lain kepatuhan wajib pajak adalah masih banyak masyarakat yang beranggapan negatif terhadap petugas pajak, hal ini memerlukan upaya untuk meningkatkan pelayanan yang baik agar terciptanya kepuasan bagi wajib pajak dalam pelaksanaan perpajakan.

Pelaksanaan pemungutan pajak bumi dan bangunan bukan hanya tugas dari pada pegawai kantor pajak saja, tetapi juga melalui kerja sama aparat pemerintah daerah maupun pejabat yang terkait, serta tidak terlepas kerjasama dari masyarakat wajib pajak sendiri untuk membantu kelancaran penerimaan pajak bumi dan bangunan. Laksito (2014) menjelaskan bahwa pada dasarnya faktor yang menghambat pembayar pajak adalah masalah kesadaran masyarakat, dimana masyarakat perlu diberi pengarahan bahwa pajak merupakan kewajiban dan hak setiap warga negara untuk ikut serta dalam pembangunan. Kesadaran dalam membayar pajak muncul dari motivasi wajib pajak, terdapat satu faktor eksternal yang juga mempengaruhi wajib pajak dalam patuh tidaknya membayar pajak yaitu sanksi pajak. Yusnidar (2015) menjelaskan fungsi sanksi adalah digunakan sebagai cara untuk mengatur sekelompok populasi untuk memenuhi aturan yang ditentukan. Salah satu upaya yang bisa dilakukan adalah dengan melakukan sosialisasi kepada masyarakat. Sosialisasi yang diberikan kepada masyarakat dimaksudkan untuk memberikan pengertian kepada masyarakat akan pentingnya membayar pajak serta sanksi jika melalaikan kewajiban membayar pajak.

Saat ini kota Batu adalah sebagai salah satu daerah di Jawa Timur yang berkembang dengan pesat dalam pembangunan wilayahnya, berbagai pembangunan fasilitas sarana infrastruktur dan program-program pembangunan dilaksanakan untuk peningkatan kesejahteraan masyarakat di wilayahnya. Guna mendukung kegiatan operasional tersebut pemerintah kota Batu banyak mengandalkan pendapatan asli daerah. Dari beberapa sumber pendapatan asli daerah kota Batu saat ini didominasi dari pendapatan sektor pajak daerah meliputi pajak hotel, restoran, hiburan, reklame, penerangan jalan, parkir, air bawah tanah, bumi dan bangunan, bea perolehan hak atas tanah dan bangunan serta lain-lain yang sah menurut peraturan yang berlaku. Dari berbagai sumber tersebut hingga saat ini pendapatan asli daerah kota Batu setiap tahunnya selalu mengalami peningkatan dari target yang ditentukan setiap tahunnya. Berikut disajikan pendapatan asli daerah kota Batu pada tiga tahun terakhir:

Tabel 1. Pendapatan Asli Daerah Kota Batu

\begin{tabular}{ccc}
\hline No & Tahun & $\begin{array}{c}\text { Pendapatan Asli Daerah } \\
\text { (dalam Rp) }\end{array}$ \\
\hline 1 & 2016 & 117.751 .331 .260 .21 \\
\hline 2 & 2017 & $145.865 .571 .206,69$ \\
\hline 3 & 2018 & $129.746 .047 .166,50$ \\
\hline
\end{tabular}

Sumber: Badan Keuangan Daerah kota Batu, 2019 
Dari tabel di atas menujukkan bahwa pendapatan asli daerah Kota Batu dari tahun selama tiga tahun terakhir meningkat, namun pada tahun 2018 pendapatan asli daerah kota batu menurun yaitu mencapai Rp. 129.746.047.166,50. Berkaitan dengan hal tersebut, pemerintah kota Batu menetapkan pendapatan sektor pajak bumi dan bangunan (PBB) sangat diandalkan guna meningkatkan penerimaan pendapatan daerah sehingga bisa mendukung pembangunan sehingga diharapkan dapat meningkatkan taraf kehidupan masyarakatnya. Dalam hal ini diharapkan pemerintah daerah kota Batu bisa menyusun suatu kebijakan yang tepat serta dapat dilaksanakan dengan baik dalam kondisi nyata dan memberikan manfaat yang optimal bagi masyarakat maupun pemerintah sehingga dalam hal ini perlu adanya peningkatan partisipasi masyarakat.

Untuk meningkatkan penerimaan sektor PBB, maka perlu adanya upaya untuk mendorong peningkatan kesadaran dan kepedulian masyarakat. Salah satunya saat ini yang telah dikembangkan adalah sistem pemungutan PBB adalah Official Assessment System (OAA), dimana sistem pemungutan tersebut jumlah pajak yang harus dilunasi atau terutang oleh wajib pajak dihitung dan ditetapkan oleh fiskus atau petugas pajak. Dalam sistem OAA ini wajib pajak bersifat pasif sedangkan fiskus bersifat aktif (Jati, 2016). Walaupun petugas pajak telah aktif namun tanpa adanya kesadaran wajib pajak dalam membayar pajak, maka akan mengakibatkan turunnya kepatuhan wajib pajak dalam membayar pajak.

Namun pada dalam pelaksanaannya masih terdapat masalah dalam seperti masih banyak masyarakat Kota Batu kurang peduli dalam membayar pajak, masyarakat selalu menunggu saat jatuh tempo, para petugas pemungut pajak merasa kesulitan dalam mencari alamat wajib pajak untuk menyampaikan SPPT karena pindah alamat tanpa pemberitahuan. Menanggapi berbagai masalah tersebut, maka saat ini pemerintah telah membuat aturan kepada para wajib pajak yang tidak membayar pajak sesuai dengan tanggal yang ditentukan akan dikenakan sanksi denda sebesar $2 \%$, akan tetapi kesadaran masyarakat sampai saat ini dirasa masih kurang dalam melaksanakan kewajibannya dalam membayar pajak. Oleh karena itu maka diperlukan strategi peningkatan penerimaan pajak bumi dan bangunan di kota Batu agar terus selalu meningkat setiap tahunnya.

\section{TINJAUAN PUSTAKA}

Siagian (2016:29) menyatakan strategi adalah serangkaian keputusan dan tindakan mendasar yang dibuat oleh manajemen puncak dan diimplementasikan oleh seluruh jajaran suatu organisasi dalam rangka pencapaian tujuan organisasi tersebut. Sedangkan menurut Rivai dan Darsono (2015), menyatakan bahwa Strategi ialah cara dan alat yang digunakan untuk mencapai tujuan akhir (sasaran atau objektif). David \& David (2015:39) menjelaskan perumusan strategi termasuk mengembangkan visi dan misi, mengidentifikasi peluang eksternal organisasi dan ancaman, menentukan kekuatan dan kelemahan internal, menetapkan tujuan jangka panjang, menghasilkan strategi alternatif, dan memilih strategi tertentu untuk mengejar. Strategi formulasi termasuk memutuskan bisnis apa yang baru masuk, apa bisnis untuk meninggalkan, apakah akan bergabung atau membentuk usaha patungan, dan bagaimana untuk menghindari pengambilalihan. Strategi dapat diartikan sebagai rencana yang cermat mengenai kegiatan untuk mencapai sasaran khusus. Namun secara umum strategi dapat diartikan sebagai alat untuk mencapai tujuan. Salah satu faktor penting yang berpengaruh terhadap strategi peningkatan penerimaan pajak bumi dan bangunan adalah aspek ekonomi daerah tersebut. Strategi adalah perencanaan induk yang komprehensif, yang menjelaskan bagaimana perusahaan akan mencapai semua tujuan yang telah ditetapkan dan berdasarkan misi yang telah di tetapkan sebelumnya. Secara makro ekonomi, kinerja pembangunan suatu daerah dapat dilihat 
melalui laju pertumbuhan ekonominya yang diukur dari tingkat perkembangan pendapatan daerah. Semakin tinggi laju pertumbuhan ekonomi maka semakin baik kinerja pembangunan suatu daerah.

Jati (2016), mengatakan bahwa pajak sebagai suatu kewajiban menyerahkan sebagian dari kekayaan ke kas negara yang disebabkan suatu keadaan, kejadian, dan perbuatan yang memberikan kedudukan tertentu, tetapi bukan sebagai hukuman, menurut peraturan yang ditetapkan Pemerintah serta dapat dipaksakan, tetapi tidak ada jasa timbal balik dari Negara secara langsung, untuk memelihara Negara secara umum. Hidayanti, (2011) mengatakan bahwa pajak adalah iuran masyarakat kepada Negara (yang dapat dipaksakan) yang terutang oleh yang wajib membayarnya menurut peraturan-peraturan umum (undang-undang) dengan tidak mendapatkan prestasi kembali yang langsung dapat ditujukan dan yang gunanya adalah untuk membiayai pengeluaran-pengeluaran umum berhubungan tugas Negara untuk menyelenggarakan Pemerintahan.

Menurut Mardiasmo (2016:382), mengatakan bahwa Bumi adalah permukaan bumi dan tubuh bumi yang ada di bawahnya. Permukaan bumi meliputi tanah dan perairan pedalaman (termasuk rawa-rawa, tambak, perairan) serta laut wilayah Republik Indonesia. Sedangkan Bangunan adalah konstruksi teknik yang ditanam atau dilekatkan secara tetap pada tanah dan/atau perairan. Pajak Bumi dan Bangunan merupakan jenis pajak daerah yang sepenuhnya diatur oleh pemerintah dalam menentukan besar pajaknya, pajak ini penting untuk pelaksanaan dan peningkatan pembangunan serta meningkatkan kemakmuran dan kesejahteraan rakyat (Wulansepty, 2014).

\section{METODE PENELITIAN}

Penelitian ini dilakukan dengan pendekatan kualitatif yang didukung dengan metode trianggulasi. Penelitian ini dilaksanakan pada badan keuangan daerah kota Batu. Waktu pelaksanaan penelitian ini dimulai pada bulan Mei dan Juni 2019. Sampel atau informan dalam penelitian ini adalah kepala seksi penetapan dan pengelolaan data, Admin pajak bumi dan bangunan data base, Staff pengelolaan data, Kasubdit pendataan dan penilaian pajak daerah, staff profesional penilaian pajak, serta masyarakat kota batu. Teknik pengambilan informasi menggunakan purposive sampling, yaitu suatu cara pemilihan informan yang dipilih berdasarkan pertimbangan dan tujuan tertentu yang dianggap mengetahui permasalahan secara mendalam dan dapat dipercaya. Teknik pengumpulan data dengan menggunakan metode observasi, wawancara dan dokumentasi. Sumber data dalam penelitian ini adalah sumber data primer dan sekunder. Teknik analisa data menggunakan reduksi data, penyajian data dan penarikan kesimpulan. Uji kredibilitas atau tingkat kepercayaan data menggunakan teknik trianggulasi yaitu wawancara, observasi dan dokumentasi.

\section{HASIL DAN PEMBAHASAN}

Kota Batu secara resmi berdiri pada tahun 2001, hasil pemekaran dari kabupaten Malang. Kota Batu terdiri dari 3 Kecamatan yaitu: Kecamatan Kota (Batu), kecamatan Bumiaji dan kecamatan Junrejo. Terdapat 19 Desa dan 5 Kelurahan. Luas dari kota Batu adalah: 202, 800 KM persegi, yang merupakan daerah yang terkecil di wilayah kawasan Malang Raya. Pembangunan kota Batu saat ini mengandalkan kegiatan sektor pariwisata karena memiliki obyek wisata alam dan buatan yang ramai dikunjungi oleh wisatawan baik domestik maupun wisatawan manca negara, obyek wisata yang berkembang saat ini antara lain wisata Jatim Park, Ecogreen, Batu Night Spectaculer (BNS), Wisata Alam Coban Talun, Songgoriti, Permandian Cangar, Kuliner Payung atau Pharalayang dan lain sebagainya. Batu juga terdapat Kebun Apel dan pusat penjualan Bunga. Kota ini memiliki kontur yang berbukit dan cocok untuk wisata dan petualangan. 
Pendapatan asli daerah Kota Batu saat ini didominasi dari pendapatan dari sektor pajak. Sektor pajak di Kota Batu terus mengalami peningkatan dan tren melampaui target terus-menerus sejak tahun 2010. Melalui intensifikasi dan ekstensifikasi pajak serta penggalian potensi daerah, Badan Keuangan Daerah mampu mengoptimalkan pendapatan daerah untuk meningkatkan rasio kemandirian daerah. Penerimaan pajak daerah di Kota Batu berasal dari 9 sektor pajak yaitu: Pajak Hotel, Restoran, Hiburan, Reklame, Penerangan Jalan, Parkir, Air Bawah Tanah, Pajak Bumi dan Bangunan (PBB), serta Pajak Bea Perolehan Hak Atas Tanah dan Bangunan. Dari 9 sektor pajak tersebut, pada tahun 2018 secara keseluruhan tercapai lebih dari $100 \%$. Kontribusi pajak terbesar saat ini berasal dari pajak bea perolehan hak atas tanah dan bangunan, pajak bumi dan bangunan, pajak hotel, pajak hiburan, dan pajak restoran. Hal ini menujukkan bahwa perkembangan investasi di kota Batu terutama di sektor yang mendukung pariwisata berkembang dengan pesat. Dari target pajak sebesar Rp. 114.000.000.000,- sampai akhir tahun 2018 dapat terealisasi sebesar Rp. 141.910.864.554,-. Jika dibandingkan dengan penerimaan pajak tahun 2017 sebesar Rp. 113.854.303.436,- maka ada kenaikan sebesar Rp. 28.056.561.118,- atau sekitar 24,64\%. Untuk itu dari target peningkatan realisasi PAD sebesar 3,5\% kinerja pada indikator ini tercapai sebesar 70,28\%.

\section{Strategi Dalam Meningkatkan Penerimaan PBB}

Pembangunan yang semakin baik yang tentunya diharapkan akan berdampak pada kesejahteraan masyarakat yang semakin baik. Sebagai salah satu sumber penerimaan yang cukup potensial, pemerintah kota Batu juga telah melakukan beberapa strategi untuk meningkatkan penerimaan PBB. Dengan demikian, kontribusi PBB terhadap pendapatan asli daerah dapat terus meningkat. Sampai saat ini strategi yang telah dilakukan oleh badan keuangan daerah kota Batu untuk meningkatkan penerimaan PBB antara lain: (1) Melakukan sosialisasi ke masyarakat secara langsung dan juga lewat spanduk-spanduk terutama ketika menjelang jatuh tempo, artinya bahwa surat pemberitahuan pajak terutang yang berfungsi untuk memberitahukan besarnya jumlah pajak yang harus dibayarkan oleh wajib pajak. Menjelang saat jatuh tempo penarikan pajak bumi dan bangunan badan keuangan daerah kota Batu melakukan sosialisasi ke masyarakat bersama Bank Jawa Timur (Jatim) dan juga badan keuangan daerah kota Batu serta selalu memasangkan spanduk-spanduk mengenai SPPT kepada wajib pajak yang biasanya dipasang di jalan-jalan utama yang ramai. Selain itu pemasangan spanduk-spanduk juga dipasang di depan kecamatan sehingga dari pemasangan spanduk sosialisasi SPPT tersebut diharapkan masyarakat membacanya dan dapat mengingat serta menginformasikan ke masyarakat lain. ini dimaksudkan supaya warga membayarkan pajaknya dengan tepat waktu dan tidak menunggu tanggal jatuh tempo, (2) Menerbitkan surat himbauan kepada wajib pajak atau surat tagihan pajak (STP) dan melakukan door to door, artinya bahwa surat tagihan pajak PBB adalah surat yang diterbitkan oleh badan keuangan daerah kota Batu, untuk melakukan tagihan pajak yang terutang. Dalam surat pemberitahuan pajak terutang (SPPT) yang tidak atau kurang dibayar setelah lewat jatuh tempo pembayaran dan atau denda administrasi sebesar $2 \%$. Kita ketahui bahwa dasar dari penerbitan STP ini adalah ketika Wajib Pajak (WP) tidak melunasi pajak yang terutang sedangkan saat jatuh tempo pembayaran SPPT telah lewat, (3) Mengadakan pekan pembayaran pajak bumi dan bangunan bersama Bank Jatim, artinya bahwa dalam rangka memaksimalkan pemasukan daerah melalui PBB di kota Batu melalui seksi pemerintahan di masing-masing kecamatan bekerjasama dengan seluruh pemerintah desa dan bersama Bank Jatim melaksanakan pekan Pajak Bumi dan Bangunan. Pekan pembayaran pajak bumi dan bangunan adalah pelaksanaan pembayaran pajak bumi dan bangunan dalam jangka waktu satu minggu yang dilakukan di masing-masing kecamatan sebagai salah satu pelayanan badan keuangan daerah kota Batu dalam mempermudah 
pemungutan PBB bagi masyarakat, dan (4) Selalu mengadakan studi banding, yang berarti bahwa dengan adanya studi banding tersebut badan keuangan daerah kota Batu bisa melihat langsung dan mengetahui strategi-strategi antara kota Batu dan kota yang lain. Hasil ini sejalan dengan studi Hidayanti, S. d. (2011); Wulansepty (2014) yang menyatakan strategi pemungutan PBB yaitu strategi mobil keliling, strategi door to door, strategi berkoordinasi dengan RT/RW dan kelurahan.

Pada sisi yang lain, kita juga dapat mengetahui adanya faktor internal yang dimiliki dan faktor eksternal yang dihadapi oleh Badan Keuangan Daerah Kota Batu. Faktor internal yaitu kelemahan dan kekuatan serta faktor eksternal yaitu peluang dan ancaman. Kedua faktor tersebut dianalisis menggunakan analisis SWOT dan kemudian ditemukannya alternatif strategi untuk dapat meningkatkan penerimaan PBB serta secara langsung meningkatkan pelayanan. Jadi rekomendasi alternatif strategi yaitu strategi pelayanan online, strategi pembinaan dan pembinaan SDM, strategi pemutakhiran data, dan strategi sosialisasi interaktif. Salah satu faktor eksternal yang dapat mempengaruhi strategi peningkatan penerimaan PBB adalah tingkat kesadaran masyarakat dalam membayar pajak. Tingkat kesadaran masyarakat ini biasanya berkaitan dengan tingkat pendidikan masyarakat semakin tinggi tingkat pendidikan masyarakat disuatu daerah biasanya berbanding lurus dengan semakin tingginya tingkat kesadaran masyarakat. Hal ini dikarenakan masyarakat dengan tingkat pendidikan tinggi tentunya memiliki pemahaman tentang arti pentingnya pajak dalam pembangunan. Dengan demikian, masyarakat sebagai taxpayer akan dengan sukarela membayar pajak yang sudah menjadi kewajiban mereka. Untuk itu, diperlukan kerjasama yang baik antara pihak Badan Keuangan Daerah Kota Batu dan wajib pajak dalam mengatasi hal terseut.

Dengan adanya kajian mengenai lingkungan internal dan eksternal yang dilakukan, telah diketahui faktor-faktor yang dapat berpengaruh dan menghambat dalam proses ketercapaian strategi yang dilaksanakan oleh Badan Keuangan Daerah Kota Batu sehingga diharapkan dapat meminimalisir faktor kelemahan yang dimiliki oleh badan keuangan daerah Kota Batu dan mengantisipasi ancaman yang mungkin akan terjadi dalam usaha peningkatan penerimaan PBB serta memaksimalkan kekuatan yang ada dan mengoptimalisasikan peluang yang ada dalam peningkatan penerimaan PBB di Kota Batu. Namun dari hasil wawancara, diketahui tingkat kesadaran dalam hal membayar PBB masyarakat Kota Batu relatif tinggi, hal ini terbukti dengan sedikitnya masalah yang terjadi ketika menjelang jatuh tempo, yang sering menjadi masalah hanya ketika objek pajak dan wajib pajaknya berada diluar kota sehingga petugas pemungut Pajak Bumi dan Bangunan kesulitan untuk menemui dan mengirimkan SPT kepada wajib pajak.

Saat ini sektor PBB dapat diandalkan untuk meningkatkan penerimaan pendapatan daerah yang ada di kota Batu, dimana PBB merupakan iuran yang dikenakan terhadap orang atau badan yang secara nyata mempunyai hak, memiliki, menguasai dan memperoleh manfaat dari bumi dan bangunan, sehingga masyarakat harus taat atas aturan membayar pajak bumi dan bangunan. Pemerintah Kota setiap tahunnya mempunyai target dalam penerimaan PBB sebagai sumber pendapatan daerah, tetapi tidak selalu target tersebut terealisasi dengan sempurna. Terkadang juga realisasi penerimaan PBB jauh di bawah target yang telah ditetapkan, sehingga membayar pajak tepat waktu berarti ikut berperan serta memperlancar proses pembangunan karena pajak yang dibayarkan sepenuhnya digunakan untuk membangun sarana-sarana bagi kepentingan umum. Semakin meningkatnya penerimaan PBB maka akan meningkatkan pendapatan asli daerah yang tentu akan berdampak positif pada peningkatan pelayanan dan kesejahteraan masyarakat kota Batu. 


\section{REFORMASI}

ISSN 2088-7469 (Paper) ISSN 2407-6864 (Online)

Volume 10 Nomor 1 (2020)

\section{Kendala Peningkatan Penerimaan PBB}

Peningkatan penerimaan PBB merupakan sumber pendapatan terbesar bagi pemerintah, namun dalam proses pemungutannya tidak jarang mengalami kendala dan masalah seperti, terjadinya keterlambatan penyampaian SPPT kepada wajib pajak biasanya dikarenakan adanya beberapa SPPT yang keliru, sehingga perlu dilakukan pembetulan terlebih dahulu, masyarakat atau wajib pajak berada di luar kota, masyarakat selalu menunggu tanggal jatuh tempo pembayaran pajak baru di bayarkan, ada juga yang tidak membayar pajak sehingga dikenakan sanksi denda sebesar $2 \%$. Kurangnya kesadaran wajib pajak dalam membayar utang pajak yang berarti bahwa masyarakat pada umumnya menekan seminimal mungkin biaya pengeluarannya termasuk dalam perihal pengeluaran untuk membayar utang pajak, sehingga masyarakat pada umumnya baru akan membayar tagihan utang pajak ketika sudah hampir jatuh tempo pembayaran. Serta banyaknya pemilik baru tanah dan bangunan yang dengan sengaja tidak mendaftarkan tanah atau bangunanya tersebut sebagai objek pajak. Hal tersebut menunjukan bahwa tingkat kesadaran masyarakat yang masih kurang dalam melakukan kewajiban Pembayaran PBB khususnya di kota Batu. Kurangnya sarana dan prasarana dalam melakukan pelayanan pajak kepada wajib pajak, yang terkait dengan teknologi dan informasi pajak maupun fasilitas dapat menyebabkan wajib pajak enggan untuk memproses apabila terjadi kekeliruan data PBB di kota Batu, sehingga hal tersebut dapat mengakibatkan wajib pajak menunda bahkan tidak memenuhi kewajibannya untuk membayar PBB. Hasil ini sejalan dengan studi Rumengan, I. K., Saerang, D. P. E., dan Runtu, T. (2016); Prathiwi, Herawati et al. (2015) yang menyatakan bahwa kendalanya pemungutan pajak adalah masalah sumber daya manusia dan sarana prasarana pendukung, serta studi Putri (2014) yang menyatakan pesoalan dalam pungutan pajak adalah berkaitan dengan masalah tarif.

Sejak Januari tahun 2011 pemungutan PBB dialihkan dari pemerintah pusat ke pemerintah daerah. Salah satu contoh Kendala yang dihadapi oleh pemerintah adalah perbedaan data tunggakan PBB serta keterlambatan pencatatan. Adanya peralihan wewenang pemungutan PBB dari pemerintah pusat dan pemerintah daerah terkadang terdapat data tunggakan wajib pajak yang masih tercatat di pemerintah pusat dan belum terhapus, faktanya wajib pajak tersebut sudah membayar kewajibannya, sedangkan di pemerintah kota masih muncul juga data tunggakan wajib pajak tersebut. Hal ini menyebabkan data tunggakan tersebut ganda sehingga wajib pajak merasa keberatan dalam membayar PBB. Berdasarkan dari hasil wawancara dengan beberapa staf badan keuangan daerah kota Batu mengatakan bahwa jika tanggal pembayaran pajak, masih banyak wajib pajak yang tidak ada di tempat, terkadang berpindah domisili ke daerah lain, itu yang membuat kendala bagi pemungut pajak untuk mendata kembali para wajib pajak.

\section{Solusi Peningkatan Penerimaan PBB}

Adanya tingkat pertumbuhan perekonomian yang berarti juga adanya tingkat pertumbuhan pendapatan, maka seharusnya menambah juga kewajiban untuk menjadi wajib pajak, karena kewajiban perpajakan pada hakekatnya merupakan kewajiban Negara bagi masyarakat dalam rangka keikutsertaan atau peran serta rakyat dalam pembayaran negara maupun pembangunan nasional adalah sangat penting, untuk diupayakan agar kewajiban tersebut lebih didasarkan pada kesadaran dan kepatuhan masyarakat yang timbul dan dirasakan oleh wajib pajak sendiri (kepatuhan secara sukarela) dari pada hanya sebagai keharusan yang akan efektif apabila disertai dengan paksaan atau sanksi yang berlaku. Pada sisi yang lain kita ketahui bahwa Pembangunan daerah merupakan bagian integral dari pembangunan nasional, yang sangat erat kaitannya dengan proses desentralisasi pembangunan dan senantiasa perlu ditingkatkan agar laju pertumbuhan antar daerah semakin seimbang dan serasi. 
Salah satu sumber penerimaan yang diharapkan dapat membantu penyediaan dana adalah yang berasal dari sektor pajak, dalam hal ini adalah Pajak Bumi dan Bangunan. Pemerintah daerah kota Batu selama ini berusaha untuk meningkatkan penerimaan dari sektor pajak terutama $\mathrm{PBB}$, mengingat pendapatan dari sektor ini potensinya cukup besar dan belum tergali sepenuhnya. Hal ini perlu dimaklumi kerena pemerintah daerah kota Batu mengalami beberapa kendala dalam pelaksanaan pemungutan $\mathrm{PBB}$ terutama disebabkan oleh kurangnya kesadaran pada masyarakat untuk turut dalam berpartisipasi melaksanakan kewajibannya membayar PBB. Upaya untuk mengatasi hal tersebut kemudian banyak dilakukan agar penerimaan PBB di kota Batu lebih meningkat dan potensi PBB yang dimiliki kota Batu dapat tergali sepenuhnya, sehingga PBB mampu berperan dalam pembiayaan pembangunan.

Maka dari itu solusi yang tepat badan keuangan daerah kota Batu kedepannya adalah selalu mengadakan penyuluhan atau sosialisasi ke desa-desa terkait dengan pembayaran pajak secara terus menerus, melakukan sosialisasi dan seminar untuk meningkatkan sumber daya manusia dan partisipasi masyarakat dalam pengelolaan dan pembayaran PBB, mendaftarkan objek pajak yang baru, membenahi manajemen penagihan pajak dan retribusi, melaksanakan pembayaran pajak sebelum batas tanggal jatuh tempo melalui spanduk, dan media massa, melakukan himbauan langsung kepada wajib pajak, menyampaikan surat panggilan, surat teguran/surat peringatan kepada wajib pajak yang melanggar, melakukan pemetaan dan penelitian terhadap potensi-potensi pendapatan melalui kerjasama yang baik, meningkatkan kegiatan promosi dan memberikan insentif berupa keringanan pajak dan kemudahan berinvestasi bagi para investor, memaksimalkan upaya penajaman target pendapatan dengan mendasarkan pada potensi yang ada, menggunakan sistem teknologi informasi untuk mendeteksi pemenuhan kewajiban pajak, menegakkan law enforcement (memberikan sanksi) contoh, penempelan stiker belum membayar pajak di restoran, perumahan, perhotelan dan lain-lain, serta membangun organisasi perpajakan daerah berdasarkan fungsi pengelola data, fungsi pelayanan, fungsi penagihan, fungsi pemeriksaan dan yang terakhir adalah fungsi pengawasan, yang mana dengan adanya beberapa fungsi maka, akan membantu untuk memperlancar pembayaran pajak bumi dan bangunan khususnya di Kota Batu.

Selain itu badan keuangan daerah kota Batu juga mengirimkan surat agar pihak desa atau kelurahan segera mengingatkan warganya yang belum membayar pajak. Pemerintahan kota Batu selalu mengadakan beberapa program, yakni kepala desa atau lurah rutin ke masyarakat misalnya, saat agenda tertentu bisa sambil mengingatkan kepada masyarakat untuk membayar pajak. Lalu pemerintahan kota Batu melalui badan keuangan daerah menggelar pekan panutan bayar PBB. Di panduan pembayaran PBB menunjukkan bahwa wali kota Batu dan Wakil Wali Kota Batu, bersama Forum Koordinasi Pimpinan Daerah (Forkopimda) melakukan gerakan sudah bayar pajak agar bisa diikuti oleh seluruh masyarakat.

\section{KESIMPULAN}

Strategi untuk peningkatan pembayaran PBB di kota Batu cukup baik, pembayaran selama tiga tahun terakhir jumlahnya selalu meningkat, pembayaran pajak bekerja sama dengan Bank Jatim, selalu turun sosialisasi ke desa-desa, dan membuat perlombaan, dengan cara seperti ini yang bisa membantu masyarakat membayar pajak selalu lancar dan tepat waktu, dengan adanya strategi seperti ini juga akan meningkatkan penerimaan PBB di kota Batu. Kendala yang menghambat peningkatan penerimaan PBB di kota Batu adalah wajib pajak tidak berada di tempat, dan juga para wajib pajak selalu menunggu tanggal jatuh tempo yang membuat resah Pemerintah terkait dengan pemungutan pajak. Solusinya adalah selalu mengadakan sosialisasi kepada masyarakat, memberikan himbauan, 


\section{REFORMASI}

ISSN 2088-7469 (Paper) ISSN 2407-6864 (Online)

Volume 10 Nomor 1 (2020)

agar masyarakat tidak telat untuk membayar pajak serta meningkatkan sumber daya manusia dan partisipasi masyarakat dalam pengelolaan dan pembayaran PBB.

\section{DAFTAR PUSTAKA}

David, Fred R. \& David, Forest R. (2016). Manajemen Strategik: Suatu Pendekatan Keunggulan Bersaing - Konsep Edisi 15. Salemba Empat, Jakarta.

Hidayanti, S. d. (2011). Pelimpahan Pajak Bumi dan Bangunan Sektor Pedesaan dan Perkotaan (PBB P-2) dan Bea Perolehan Hak atas Tanah (BPHTB) menjadi Pajak Daerah, antara peluang dan tantangan. Jurnal WIGA, 2088-0944. Vol. 2 No. 2 September 2011 ISSN No. 2088-0944: hal. 44.

Jati. (2016). Pengaruh Sikap, Kesadaran Wajib Pajak dan Pengetahuan Perpajakan pada Kepatuhan Membayar Pajak Bumi dan Bangunan. E-Jurnal Akuntansi Universitas Udayana. Vo1.5 No.2 ISSN: 1510-1535.

Laksito, R. W. (2014). Faktor-faktor yang mempengaruhi kepatuhan pajak bumi dan bangunan (Studi pada WPOP di Kabupaten Klaten). Diponegoro Journal of Accounting, 2337-3806.

Mardiasmo (2016). Perpajakan. Penerbit CV Andi Offset. Yogyakarta.

Putri. (2014). Evaluasi Penerimaan PBB Paska UU PDRD (UU No 28 Tahun 2009) (Studi Kasus Diwilayah Kabupaten Sukoharjo). Skripsi Publikasi Fakultas Ekonomi dan Bisnis Universitas Muhammadiyah Surakarta

Prathiwi, I. A. M. A., Et Al. (2015). "Analisis Strategi Penerimaan Pajak Bumi Dan Bangunan Pedesaan Dan Perkotaan (PBB-P2) Serta Efektivitas Penerimaannya di Pemerintah Kota Denpasar Tahun 2013-2014." Jimat (Jurnal Ilmiah Mahasiswa Akuntansi S1), Vol. 3 No. 1: hal. 4-7

Rivai. A dan Darsono. P (2015). Manajemen Strategis. Jakarta: Mitra Wacana Media,

Rumengan, I. K., Saerang, D. P. E., dan Runtu, T. (2016). Analisis Efektivitas Dan Strategi Penerimaan Pajak Bumi Dan Bangunan Pedesaan Dan Perkotaan (PBB-P2) Di Dinas Pengelolaan Keuangan Pendapatan Dan Aset Kabupaten Minahasa Selatan. Jurnal Berkala Ilmiah Efisiensi. Vol. 16 No. 04. Hal. 767

Sondang P. Siagian. (2016). Sistem Informasi Manajemen. Bumi Aksara. Jakarta.

Wulansepty, D. (2014). Strategi Pemungutan PBB Kota Surabaya Terhadap Realisasi Target Penerimaan Tahun 2009-2012. Jurnal Ilmu dan Riset Akuntansi Vol.3 No.10. Sekolah Tinggi Ilmu Ekonomi Indonesia Surabaya. Diakses 20 Maret 2016. Hal.2.

Yusnidar, Johan. S. d. (2015). Pengaruh faktor-faktor yang mempengaruhi kepatuhan wajib pajak dalam melakukan pembayaran pajak bumi dan bangunan perdesaan dan perkotaan (Studi pada wajib pajak PBB-P2 Kecamatan Jombang Kabupaten Jombang). Universitas Brawijaya. Vol 4, No.1: hal : 2-5 